\title{
Improve Productivity by Implementing a Quality Management Cycle (Case Study: Internet and Financial Services Company)
}

\section{Faezeh Namazian ${ }^{1}$ and Marjan Mohamadjafari ${ }^{2 *}$}

${ }^{1} \mathrm{MSc}$ Student, Department of Industrial Engineering, Islamic Azad University, Kerman, Iran

${ }^{2}$ Assistant Professor of Industrial Engineering, Islamic Azad University, Kerman, Iran

\begin{abstract}
Improving productivity, like other components, is one of the main organizational requirements. This study presents a quality management cycle to assess the dealership of one of the Internet service providers in Kerman province during the second half of 2015 and the first half of 2016 . We initially planned and implemented a quality management system. After the first six months, in order to control Processes performed based on Scheduled planning, the efficiency of the dealers with the data envelopment analysis technique was calculated. With Malmquist index, the degree of improvement in the efficiency of the dealers was determined. In the following, as for the new risk-taking topic in the 2015 version of the quality management system, risk rating of dealers was calculated with Failure Mode Effects Analysis. In this research, using the risk-based numbering system, the priority number of the risk was compared with the determined risk number, and the unacceptable risks were specified. Finally, the results of the research were presented.
\end{abstract}

Keywords: Cycle quality management; Efficiency; Data envelopment analysis technique; Failure mode effects analysis technique; Quality management system (Iso9001:2015)

\section{Introduction}

Psomas et al. [1] the main structure of the management of all organizations is the set of systems that describe how the organization operates. The system can define by the organizational structure, responsibilities, procedures and resources needed to guide the core operations within the organization or provide common needs. The first consideration in designing a system or process is to produce the desired result. The notion that their shared processes and processes should analyze and improve is the underlying foundation of the quality management system. Productivity, efficient and effective use of resources in the production of products and services that meet the needs and desires of users [2]. This broad concept of productivity highlights the close relationship between productivity and quality. An assessment of the performance of organizations is essential in guiding their future decisions [3]. In this regard, the productivity of organizations should calculate in order to monitor future economic growth trends in future decisions. One of the most suitable tools for calculating the efficiency of decision-makers, the Data Envelopment Analysis (DEA) technique, used as a non-parametric method, is used. Using failure mode effects analysis technique (FMEA), the most important and basic causes of low productivity are determined [4]. A management tool in the manufacturing sector is used to predict and manage risks and to estimate the size of the threats. In fact, this technique systematically minimizes external threats. In fact, this technique shows external threats as a quantitative shape.

In this paper, we will implement a quality management system to establish a quality management cycle. Using the Data Envelopment Analysis method, the performance of agents in the second half of 2015 and the first six months of 2016 will be calculated and will be monitored for productivity by using Malmquist Index, and the efficiency improvement rate will be measured over the past six months. At this stage, in addition to efficiency, the risks identified in all dealers will be assessed and analyzed by analyzing potential malfunction scenarios and identifying unacceptable risks by determining the acceptable risk weighting number. Finally, efficiency indicators and risk analysis will be discussed.

\section{Literature Review}

Shewhart [5] promoted the understanding of quality and quality management and accelerated the development of quality management. Deming [6] noted that the role of quality management in business is to create the constancy of purpose for the improvement of products and to create a system that can produce quality outcomes. In order to ensure the quality level of cultural relic's protection project, use PDCA cycle management method in the construction process to manage and control major factors of cultural relics protection such as people, material, construction method, natural environment, etc. [7]. Carry out operation by strictly follow the PDCA cycle management sequence of four stages and eight procedures to guarantee the quality of cultural relics protection effectively. Presenting an approach for the development of such a quality control loop including interfaces to associated processes in product development, production planning and quality management as well as a first examination of affected process parts in production planning is subject of this paper [8]. One of the most effective and efficient tools for calculating the efficiency of decision-making units is the DEA technique, which is used as a nonparametric method [9]. Emami [3] in the inventory of productivity calculations, the Malmquist index and the efficiency values derived from the DEA method have been used. This index was originally expressed in 1953 by a person named Malmquist in the field of consumer theory. Then it was introduced in 1982 by Kevs et al. in the framework of the theory of production. In 1992, Fare et al. Calculated Malmquist's index based on the performance values obtained through the data envelopment analysis model and showed that the factors of production factor distance are the same as the inverse of the Farrell's

*Corresponding author: Marjan Mohamadjafari, Assistant Professor of Industrial Engineering, Islamic Azad University, Kerman, Iran, Tel: +60 3-7967 7022; E-mail: marjan_mohamadjafari@yahoo.com, faezehnamazian@gmail.com

Received April 24, 2018; Accepted June 13, 2018; Published June 20, 2018

Citation: Namazian F, Mohamadjafari M (2018) Improve Productivity by Implementing a Quality Management Cycle (Case Study: Internet and Financial Services Company). Ind Eng Manage 7: 256. doi:10.4172/2169-0316.1000256

Copyright: (c) 2018 Namazian F, et al. This is an open-access article distributed under the terms of the Creative Commons Attribution License, which permits unrestricted use, distribution, and reproduction in any medium, provided the original author and source are credited. 
Citation: Namazian F, Mohamadjafari M (2018) Improve Productivity by Implementing a Quality Management Cycle (Case Study: Internet and Financial Services Company). Ind Eng Manage 7: 256. doi:10.4172/2169-0316.1000256

Page 2 of 6

performance values, which are to be taken into consideration Efficiency values derived from DEA linear programming method, calculation of productivity by new method was possible. Since 2000 , this method is one of the most widely used risk assessment methods in all industries [10]. Using the Frequency of Failure Analysis (FMEA) technique, the most important and basic causes of low productivity are determined. A management tool in the manufacturing sector is used to predict and manage risks and to estimate the size of the threats. In fact, this technique systematically minimizes external threats. Seraji et al. to determine the critical levels, three levels are used and the risk-taking number is obtained and, by comparison with the priority number, risks are considered unacceptable $[11,12]$.

\section{Implementing a quality management system}

At this point, we begin by implementing a quality management system in the organization in the form of a quality management cycle (PDCA) and presenting it in the form of the following Figure 1.

\section{Efficiency measurement using data envelopment analysis technique}

At this point, we analyse the efficiency of the dealers using the data envelopment analysis technique. The realm of this research is the Bardsir, Rawar, Koohbanan, Rhine and Mahan dealerships, one of the companies offering Internet services in Kerman province. In addition, the domain of time, the data for model variables for the second half of the year 2015 and the first six months of the year are 2016. Below are the tables of selected criteria and indicators to measure the performance of the dealers. It is worth noting that these criteria and indicators have been determined based on intellectual storm meetings between unit managers (Table 1).

The efficiency values for each indicator in the following diagrams are calculated using DEAP software (Figures 2-7).

At this stage to compare the performance of agencies over the last six months and measuring the efficiency of the criteria we use Malmquist. All operations related to the modelling are designed by the DEAP specialized software designed to compute data envelopment analysis. Below with using tables for distance functions when available in Table 2, productivity values are determined based on the criteria specified in the two periods of the second six-month period 2015 and the first six months of the year 2016 for the dealers.

Tables 2-4 show the changes in total productivity and its components for dealers according to the criteria set. Considering the input-axis nature of the Malmquist index in this study, this is interpreted as if $\mathrm{MI}<1$ increase in productivity growth and performance improvements, if $\mathrm{MI}>1$ shows a decrease in productivity growth, and if $\mathrm{MI}=1$ indicates that none There has been no change in productivity growth for $t$ and $t+1$ times. With regard to the results of the changes in efficiency, technology and productivity index based on the criteria set, Productivity Increased in the Bardsir, Ravar and Kohbanan agencies in

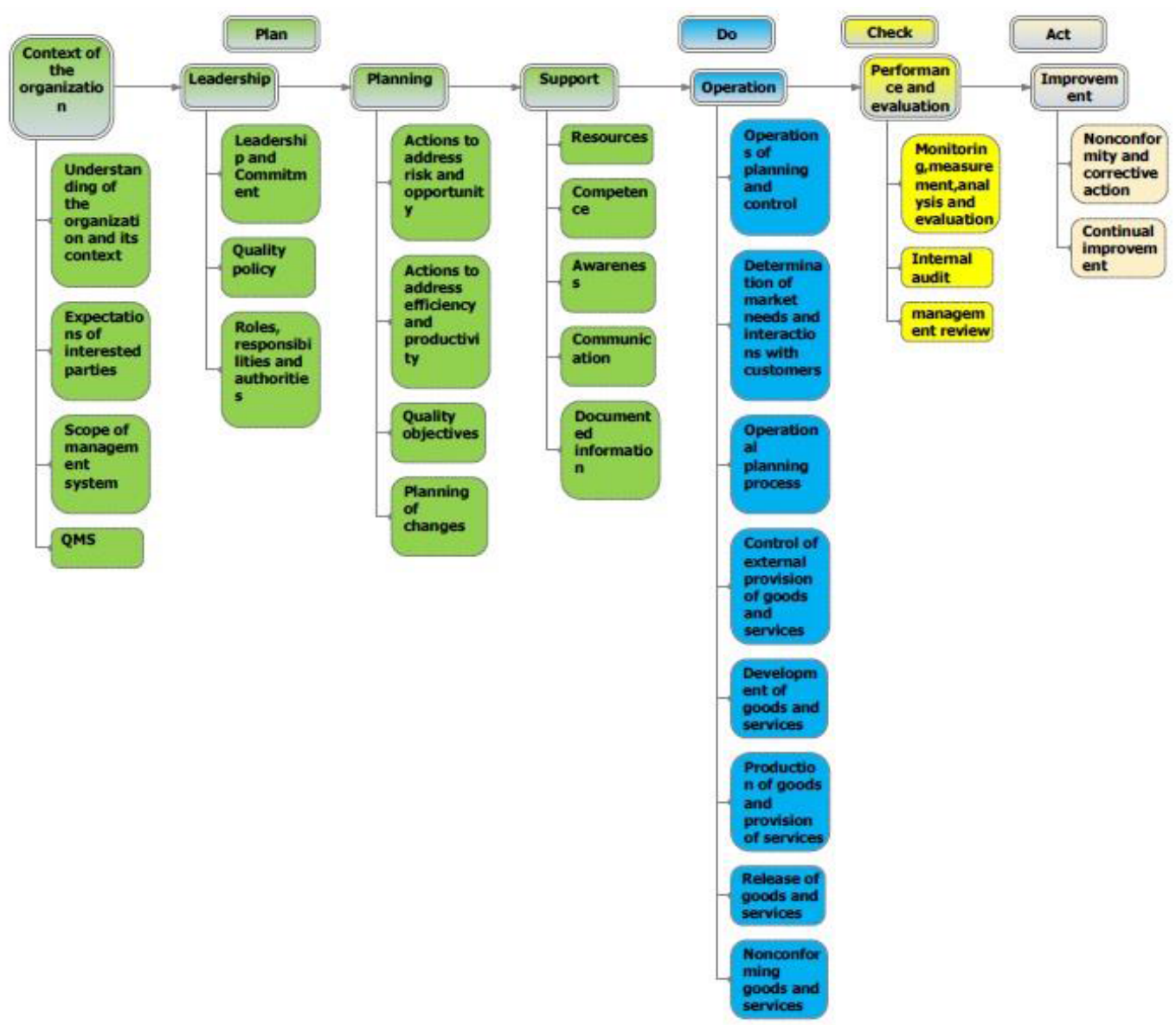

Figure 1: Implementation of quality management system. 
Citation: Namazian F, Mohamadjafari M (2018) Improve Productivity by Implementing a Quality Management Cycle (Case Study: Internet and Financial Services Company). Ind Eng Manage 7: 256. doi:10.4172/2169-0316.1000256

\begin{tabular}{|c|c|c|c|}
\hline $\begin{array}{c}\text { Efficiency } \\
\text { metrics }\end{array}$ & Indicator & Row & $\begin{array}{c}\text { Input } \\
\text { Output/ }\end{array}$ \\
\hline \multirow{3}{*}{ ADSL } & Number of ADSL lines collected & 01-Jan & Input \\
\cline { 2 - 4 } & Agency area & 01-Feb & Input \\
\cline { 2 - 4 } & Number of Agency personnel & 01-Mar & Input \\
\cline { 2 - 4 } & Total number of home users & 01-Apr & Output \\
\cline { 2 - 4 } & Total number of business subscribers & 01-May & Output \\
\hline \multirow{4}{*}{ POS } & The number of ADSL lines is set & 01-Jun & Output \\
\cline { 2 - 4 } & Number of POS devices collected & 02-Jan & input \\
\cline { 2 - 4 } & Number of POS devices installed & 02-Feb & Output \\
\cline { 2 - 4 } & Average transaction device & 02-Mar & Output \\
\cline { 2 - 4 } & Transaction amount & 02-Apr & Output \\
\hline \multirow{4}{*}{ Quality } & Number of ADSL lines collected & 03-Jan & input \\
\cline { 2 - 4 } & Number of POS devices collected & 03-Feb & input \\
\cline { 2 - 4 } & New subscriber number & 03-Mar & Output \\
\cline { 2 - 4 } & Number of infrastructure ready for & 03-Apr & Output \\
\cline { 2 - 4 } & operation & 04-Apr & Output \\
\hline & Bandwidth & \\
\hline
\end{tabular}

Table 1: Selected indicators for assessing the effectiveness of agencies.

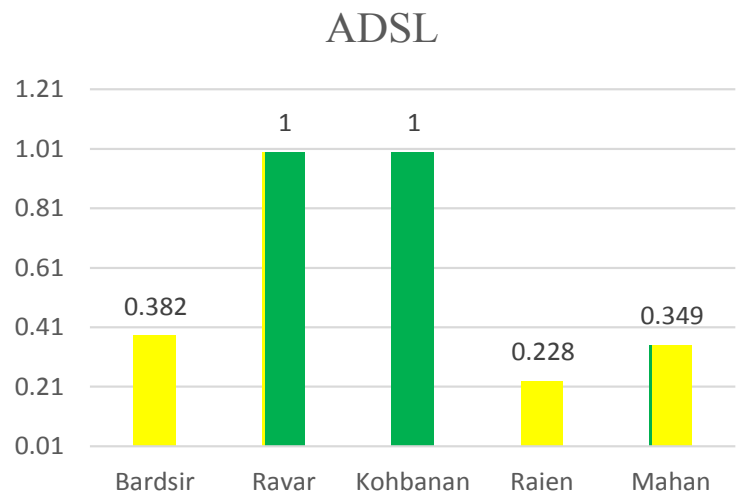

Figure 2: The efficiency value of ADSL the second six months of 2015.

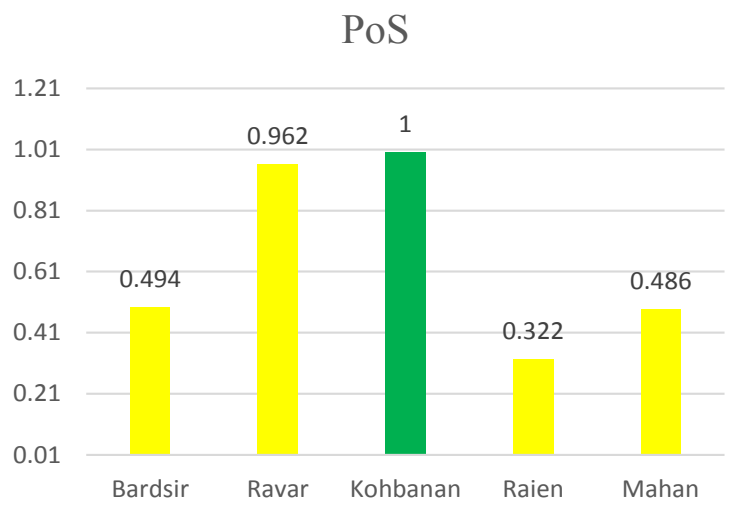

Figure 3: The efficiency value of POS the second six months of 2015.

the ADSL criterion, in Bardsir, Ravar, Kohbanan and Mahan agencies in the POS criterion and in Ravar, Raien and Mahan agencies in the Quality criterion.

\section{Risk measuring using failure mode effects analysis technique}

According to the company's management, the exact reason for the decline in efficiency in dealers is determined. The risks inherent in the dealers' collection, prioritization, and using the FMEA technique,

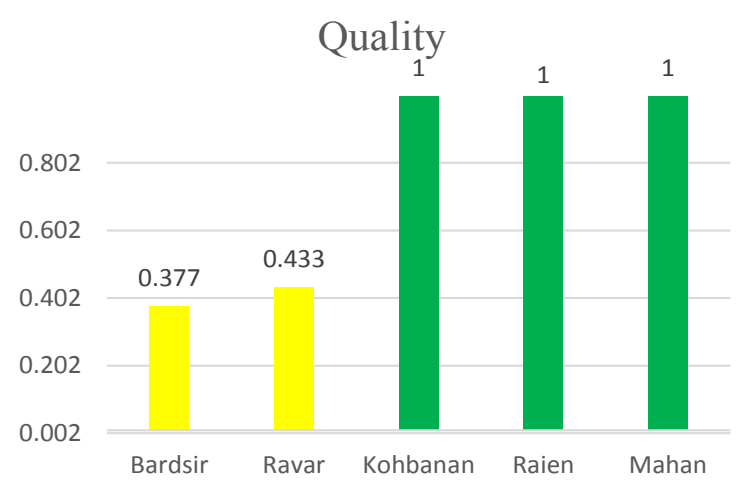

Figure 4: The efficiency value of Quality the second six months of 2015.

\section{ADSL}

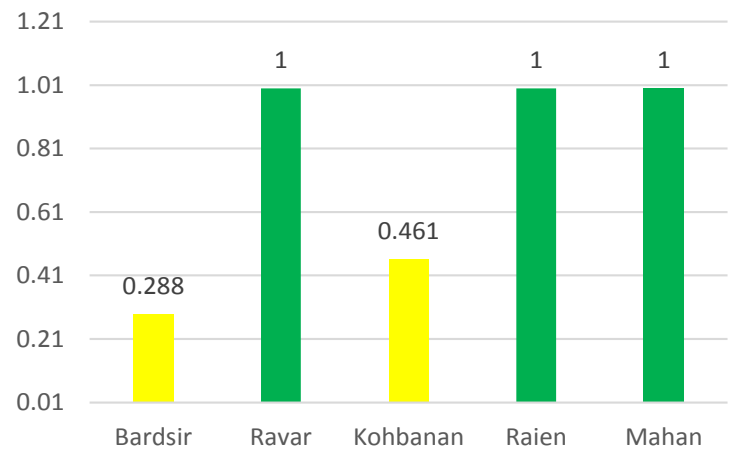

Figure 5: The efficiency value of ADSL the first six months of 2016.

\section{PoS}

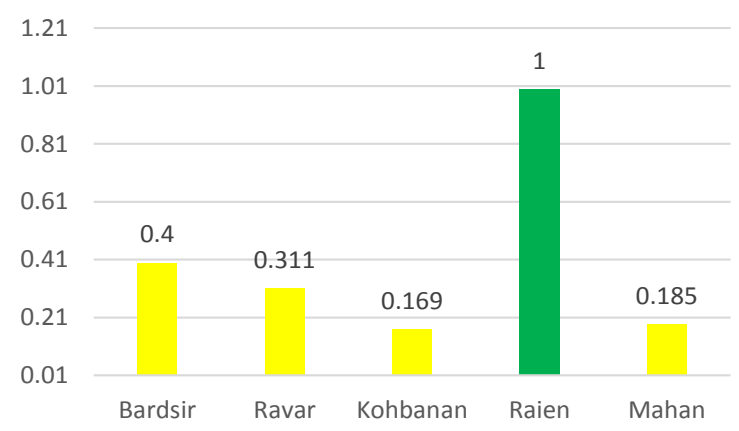

Figure 6: The efficiency value of POS the first six months of 2016.

priority number, risk, were calculated. Ultimately, unacceptable risks and suggested solutions were presented to them. In this section, after determining the risks of the dealers, the analysis and prioritization of the risks with regard to the scoring of the severity of the effect, the likelihood of occurrence and the probability of the discovery has been made and according to the comparison of the priority number of the risk obtained with the number defined as the risk criterion, if necessary Preventive measures will be taken to reduce existing risks.

Table 5 lists the risks involved in the dealership. In Table 6, priority risk was calculated in dealers. To identify acceptable and unacceptable risks according to risk priority number obtained from the measure of risk used. 
Citation: Namazian F, Mohamadjafari M (2018) Improve Productivity by Implementing a Quality Management Cycle (Case Study: Internet and Financial Services Company). Ind Eng Manage 7: 256. doi:10.4172/2169-0316.1000256

Page 4 of 6

\begin{tabular}{|c|c|c|c|c|}
\hline & \multicolumn{4}{|c|}{ First six months of the year 2016 } \\
\hline Row & Agency & Productivity Index MI & Technological changes TC \\
\hline 1 & Bardsir & 0.792 & 1.051 & 0.753 \\
\hline 2 & Ravar & 0.977 & 0.977 & 0.697 \\
\hline 3 & Kohbanan & 0.321 & 1.058 \\
\hline 4 & Raien & 4.635 & 1.541 \\
\hline
\end{tabular}

Table 2: Total productivity and its components changes for agents based on ADSL scale.

\begin{tabular}{|c|c|c|c|c|}
\hline \multicolumn{5}{|c|}{ First six months of the year 2016 } \\
\hline Row & Agency & Productivity Index MI & Technological changes TC \\
\hline 1 & Bardsir & 0.863 & 1.067 \\
\hline 2 & Ravar & 0.407 & 1.262 & 0.809 \\
\hline 3 & Kohbanan & 0.194 & 1.149 \\
\hline 4 & Raien & 6.271 & 2.017 \\
\hline 5 & Mahan & 0.497 & 1.306 & 0.169 \\
\hline
\end{tabular}

Table 3: Total productivity and its components changes for agents based on POS scale.

\begin{tabular}{|c|c|c|c|c|}
\hline \multicolumn{5}{|c|}{ First six months of the year 2016 } \\
\hline Row & Agency & Productivity Index MI & Technological changes TC \\
\hline 1 & Bardsir & 1.078 & 0.702 \\
\hline 2 & Ravar & 0.668 & 0.668 & 1.535 \\
\hline 3 & Kohbanan & 1.179 & 1.179 & 0.873 \\
\hline 4 & Raien & 0.534 & 0.534 & 0.551 \\
\hline 5 & Mahan & 0.18 & 0.18 \\
\hline
\end{tabular}

Table 4: Total productivity and its components changes for agents based on quality scale.

\begin{tabular}{|r|l|}
\hline \multicolumn{1}{|l|}{ Row } & Risks in dealers \\
\hline 1 & Shortage of manpower in dealership \\
\hline 2 & The currency turbulence and its impact on prices of imported goods \\
\hline 3 & The complexity of the design software environment \\
\hline 4 & Lack of timely notification to request product unit warehouse \\
\hline 5 & Competitor festival \\
\hline 6 & Fiber clearing lines by telecommunications \\
\hline 7 & The presence of new technologies in competing companies \\
\hline 8 & Failure to answer calls by personnel \\
\hline 9 & Lack of technical knowledge of personnel \\
\hline 10 & Inferior equipment \\
\hline 11 & Noise in telecommunication equipment \\
\hline
\end{tabular}

Table 5: Risks in deaers.

In Figure 8, the numbers of risk priority and crisis levels are used to calculate the risk factor number. Using the risk-based number, appropriate corrective and preventive measures are provided for unacceptable risks. After determining the rating and priority number of the risk, the first number in rank 3 will be considered as acceptable risk level it will be introduced. This according to the Figure 8, 1.68, has been identified as acceptable risk level. Further, according to the risk number, all priority numbers are compared with the specified risk level, and the priority numbers of the risk that exceed the risk criteria are considered as unacceptable Risk and suggestions will be made according to them (Table 7).

\section{Discussion}

According to the results obtained from using the quality management system in the framework of quality management cycle using productivity and risk factors, productivity changes indicate that productivity in $60 \%$ of dealers based on ADSl and Quality criteria and in $80 \%$ of Dealers based on POS criteria have increased. The following are presented as corrective and preventive measures regarding unacceptable risks.

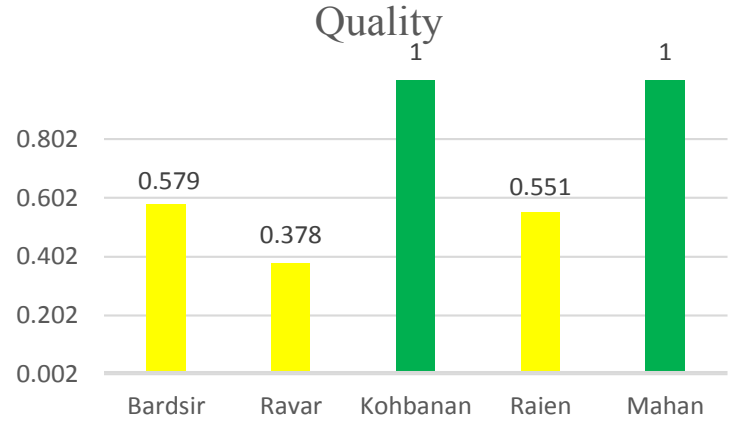

Figure 7: The efficiency value of quality the first six months of 2016.

\section{Conclusion and Suggestions}

The currency turbulence and its impact on prices of imported goods

Due to the fact that the forecast of the future price of the currency, based on the results of the past, includes an uncertain trend, and the experts cannot provide the required import goods with the help of a price survey of the currency. It was decided to reduce the risk of buying goods abroad by replacing domestic goods.

\section{The complexity of the design software environment}

Due to the fact that the risk assessment of the new changes in the system was not carried out in full and in accordance with the proposed method, it was decided to revise the feasibility study of new changes in the system. The new feasibility study includes the following steps:

1. Familiarity with the details of the project presented in the company 
Citation: Namazian F, Mohamadjafari M (2018) Improve Productivity by Implementing a Quality Management Cycle (Case Study: Internet and Financial Services Company). Ind Eng Manage 7: 256. doi:10.4172/2169-0316.1000256

Page 5 of 6

\begin{tabular}{|c|c|c|c|c|c|c|c|c|c|}
\hline Row & $\begin{array}{c}\text { Potential } \\
\text { consequence }\end{array}$ & $\begin{array}{l}\text { The effect of potential } \\
\text { consequences }\end{array}$ & $\begin{array}{l}\text { Intensity } \\
\text { of effect } \\
\text { (S) }\end{array}$ & $\begin{array}{l}\text { Causes of } \\
\text { occurrence }\end{array}$ & $\begin{array}{c}\text { Probability of } \\
\text { occurrence (0) }\end{array}$ & $\begin{array}{l}\text { Current control } \\
\text { methods }\end{array}$ & $\begin{array}{l}\text { Probability } \\
\text { of discovery } \\
\text { (D) }\end{array}$ & $\begin{array}{l}\text { Risk Priority } \\
\text { Number } \\
\text { (RPN) }\end{array}$ & $\begin{array}{l}\text { Crisis } \\
\text { level }\end{array}$ \\
\hline 1 & $\begin{array}{l}\text { Shortage of } \\
\text { manpower in } \\
\text { representation }\end{array}$ & $\begin{array}{l}\text { Losing the labor market - } \\
\text { reducing quality }\end{array}$ & 7 & $\begin{array}{c}\text { Poor absorption } \\
\text { system performance }\end{array}$ & 0.6 & $\begin{array}{l}\text { Continuous review } \\
\text { of job inventory and } \\
\text { staff recruitment } \\
\text { requirements }\end{array}$ & 0.4 & 1.68 & 3 \\
\hline 2 & $\begin{array}{l}\text { The currency } \\
\text { turbulence and its } \\
\text { impact on prices of } \\
\text { imported goods }\end{array}$ & $\begin{array}{c}\text { Reduce company revenue - } \\
\text { Losing a job market }\end{array}$ & 6 & Financial problems & 0.8 & $\begin{array}{c}\text { Forecast future } \\
\text { currency prices } \\
\text { according to past } \\
\text { results }\end{array}$ & 0.8 & 3.84 & 3 \\
\hline 3 & $\begin{array}{l}\text { The complexity of } \\
\text { the design software } \\
\text { environment }\end{array}$ & $\begin{array}{c}\text { Dissatisfaction and reduced } \\
\text { staff performance }\end{array}$ & 8 & $\begin{array}{l}\text { Failure to check the } \\
\text { new system risks }\end{array}$ & 0.6 & $\begin{array}{l}\text { The feasibility of new } \\
\text { system changes risk }\end{array}$ & 0.5 & 2.4 & 3 \\
\hline 4 & $\begin{array}{l}\text { Lack of timely } \\
\text { notification to } \\
\text { request product unit } \\
\text { warehouse }\end{array}$ & $\begin{array}{c}\text { Failure to deliver on time the } \\
\text { requested goods }\end{array}$ & 4 & $\begin{array}{l}\text { Staff dissatisfaction } \\
\text { and customers }\end{array}$ & 0.4 & $\begin{array}{l}\text { Review daily } \\
\text { requests and } \\
\text { prioritize them }\end{array}$ & 0.3 & 0.48 & 1 \\
\hline 5 & Competitor festival & Loss of customer & 7 & $\begin{array}{c}\text { Identify the job market } \\
\text { and the new customer } \\
\text { needs }\end{array}$ & 0.7 & $\begin{array}{c}\text { Formation of groups } \\
\text { to identify customer } \\
\text { needs }\end{array}$ & 0.5 & 2.45 & 3 \\
\hline 6 & $\begin{array}{l}\text { Fiber clearing lines by } \\
\text { telecommunications }\end{array}$ & $\begin{array}{l}\text { Losing a customer - lack of } \\
\text { market development }\end{array}$ & 9 & $\begin{array}{l}\text { The exclusivity of a } \\
\text { number of lines by } \\
\text { telecommunications }\end{array}$ & 1 & $\begin{array}{l}\text { Provide alternative } \\
\text { internet }\end{array}$ & 0.4 & 3.6 & 3 \\
\hline 7 & $\begin{array}{c}\text { The presence of } \\
\text { new technologies in } \\
\text { competing companies }\end{array}$ & $\begin{array}{l}\text { Losing a customer - lack of } \\
\text { market development }\end{array}$ & 4 & $\begin{array}{l}\text { Developing new IT } \\
\text { technologies }\end{array}$ & 0.4 & $\begin{array}{l}\text { Modeling the } \\
\text { technologies used by } \\
\text { rival companies }\end{array}$ & 0.5 & 0.8 & 1 \\
\hline 8 & $\begin{array}{l}\text { Failure to answer } \\
\text { calls by personnel }\end{array}$ & customer dissatisfaction & 7 & $\begin{array}{l}\text { High work volume - } \\
\text { Non-commitment of } \\
\text { personnel }\end{array}$ & 0.4 & $\begin{array}{l}\text { Changing the late } \\
\text { shift with new forces }\end{array}$ & 0.4 & 1.12 & 2 \\
\hline 9 & $\begin{array}{l}\text { Lack of technical } \\
\text { knowledge of } \\
\text { personnel }\end{array}$ & customer dissatisfaction & 7 & $\begin{array}{c}\text { Lack of training } \\
\text { classes on technical } \\
\text { and specialized topics }\end{array}$ & 0.4 & $\begin{array}{l}\text { Complete the } \\
\text { training needs } \\
\text { assessment forms } \\
\text { and continuously } \\
\text { control them }\end{array}$ & 0.3 & 0.84 & 2 \\
\hline 10 & Inferior equipment & $\begin{array}{l}\text { Customer dissatisfaction - } \\
\text { reducing company credit }\end{array}$ & 8 & $\begin{array}{l}\text { Poor network system } \\
\text { performance }\end{array}$ & 0.4 & $\begin{array}{l}\text { Supplier assessment } \\
\text { - Practical testing } \\
\text { before installation }\end{array}$ & 0.3 & 0.96 & 2 \\
\hline 11 & $\begin{array}{l}\text { Noise in } \\
\text { telecommunication } \\
\text { equipment }\end{array}$ & $\begin{array}{l}\text { Customer dissatisfaction - } \\
\text { reducing company credit }\end{array}$ & 5 & $\begin{array}{l}\text { Radio Frequency } \\
\text { Interference }\end{array}$ & 0.5 & Practical test & 0.3 & 0.75 & 2 \\
\hline
\end{tabular}

Table 6: The effect of potential consequences and probability of occurrence.

Risk level determination

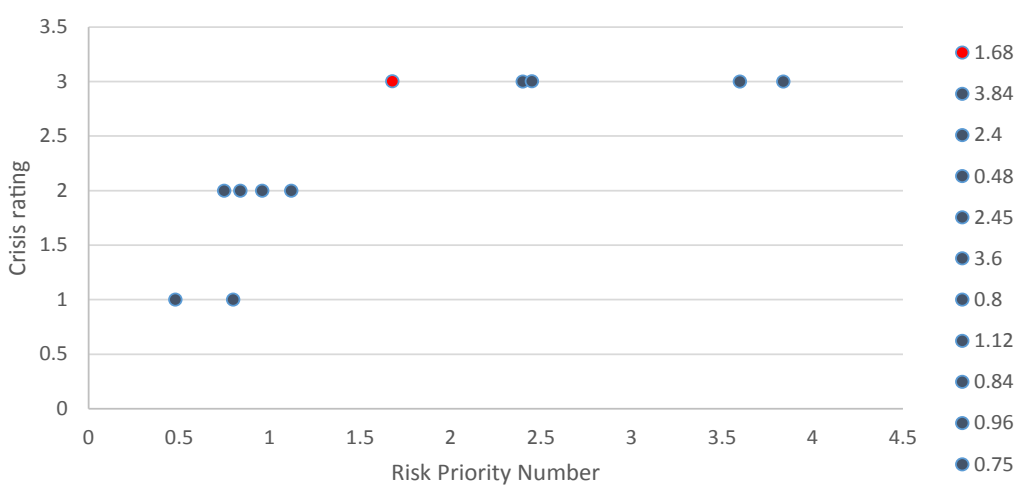

Figure 8: Determination of acceptable risk level.

2. Identify the strengths, weaknesses, opportunities and threats created by new changes in the system using SWOT analysis.

3. Economic review, how to provide resources and study the market if using new changes

4. Estimating income, costs and expenses resulting from new changes in the system
5. Determination of financial and economic indicators of the plan

6. The final analysis of the plot.

Competitor festival: Because the formation of groups to identify customers' needs could not properly study the market, it was decided to use the modeling method. The modeling of the rival companies' festival includes the following steps: 
Citation: Namazian F, Mohamadjafari M (2018) Improve Productivity by Implementing a Quality Management Cycle (Case Study: Internet and Financial Services Company). Ind Eng Manage 7: 256. doi:10.4172/2169-0316.1000256

Page 6 of 6

\begin{tabular}{|c|c|c|c|c|}
\hline Row & Potential Risks & Risk Priority Number & Risk Cycle Number & Acceptable/Unacceptable \\
\hline 1 & Shortage of manpower in representation & 1.68 & 1.68 & Acceptable \\
\hline 2 & $\begin{array}{l}\text { The currency turbulence and its impact on prices of } \\
\text { imported goods }\end{array}$ & 3.84 & & Unacceptable \\
\hline 3 & The complexity of the design software environment & 2.4 & & Unacceptable \\
\hline 4 & $\begin{array}{l}\text { Lack of timely notification to request product unit } \\
\text { warehouse }\end{array}$ & 0.48 & & Acceptable \\
\hline 5 & Competitor festival & 2.45 & & Unacceptable \\
\hline 6 & Fiber clearing lines by telecommunications & 3.6 & & Unacceptable \\
\hline 7 & $\begin{array}{c}\text { The presence of new technologies in competing } \\
\text { companies }\end{array}$ & 0.8 & & Acceptable \\
\hline 8 & Failure to answer calls by personnel & 1.12 & & Acceptable \\
\hline 9 & Lack of technical knowledge of personnel & 0.84 & & Acceptable \\
\hline 10 & Inferior equipment & 0.96 & & Acceptable \\
\hline 11 & Noise in telecommunication equipment & 0.75 & & Acceptable \\
\hline
\end{tabular}

Table 7: Comparison of priority number risk with risk level specified.

1. Study and implement the company's capabilities

2. Search for successful competitor companies in past periodicals

3. Study the process of identifying the market of customers and how to hold the festivals

4. Analysis and analysis of the differences between the process of conducting the festival of rival company and its company

5. Match the differences in the process of running the rival company and its company festival.

Fiber clearing lines by telecommunications: Because of the exclusivity of a number of lines by telecommunication, a number of internet-based alternatives were created by the company for customers, but due to the low speed of existing Internet, they were not wellresponsive customers. It was decided to reduce the number of internet lines replaced and their facilities, including internet speed, discounts and more.

\section{References}

1. Psomas E, Fotopoulos C, Kafetzopoulos D (2010) Critical factors for effective implementation of ISO 9001 in SME service companies. Managing Service Quality 20: 440-457.

2. Kumbhar SK, Niranjan MR, Satpute ST (2014) Assembly line production improvement by optimization of cycle time. IRAJ 2: 29-33.
3. Meybodi I (2000) Principles of measurement of efficiency and productivity (scientific and applied). Institute for Business Studies and Research.

4. Gurbuz F (2017) Strategy development with SWOT analysis on manufacturing companies in rapid growth: A ceramic industry application. New Trends Issues Proceedings on Humanities Social Sci 4: 1-12.

5. Shewhart WA (1930) Economic quality control of manufactured product. Bell Syst Tech 9: 364-389.

6. Deming WE (1982) Quality, productivity, and competitive position Massachusetts Institute of Technology, Center for Advanced Engineering Study pp: 1-373

7. Huang W (2011) The application of PDCA cycle management in quality control of cultural relics protection. Engineering Educ Management 112: 625-630.

8. Koch J, Greitemann J, Plehn C, Reinhart G (2013) Cycle oriented quality management at the interface of product development and production planning IFIP Advances in Information and Communication Technol 409: 491-499.

9. Matin Z, Fazlami J, Yazdani M, Reza H, Birjai H, et al. (2010) The relationship between strategic orientation and organizational performance using a balanced scorecard approach. Tehran Business J 2: 97-112.

10. Hannah K, Chau K, Leung-Chi K, SongbaiShu-ChuenTsui L (2011) A structured SWOT approach to develop strategies for the government of Macau. SAR J Strategy Management 4: 62-81.

11. Seraji M, Preacher $M$, Najmeh $S$ Analysis of the error and its effects in the machine tool workshop by determining the level of the crisis.

12. https://www.europeanceo.com/business-and-management/total-qualitymanagement-three-case-studies-from-around-the-world/ 